\title{
Victorian Literature
}

and Culture

Volume 40, Number 2, 2012

,

arath 16.

औ

(4)

tar.

25.

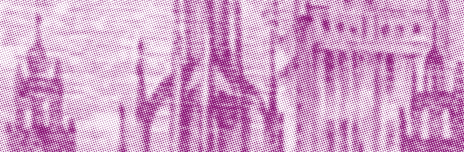

קili!

tominim:

ine

1.7ng

\}

fravorion

serestax

.

(1014)

(X)

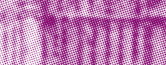

$5=1.1$.

PWpipip

Trimo

If

Tppopip

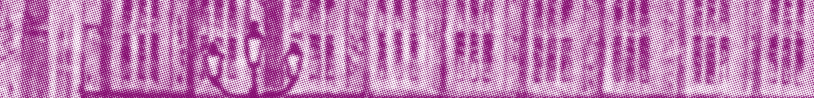

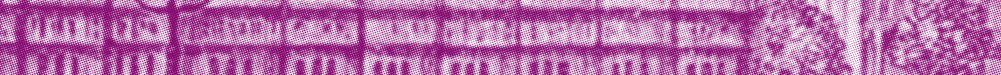

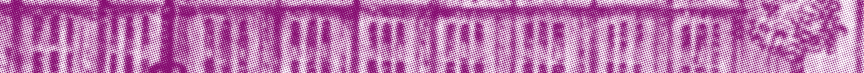

13.

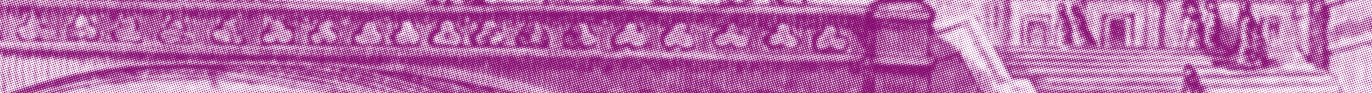

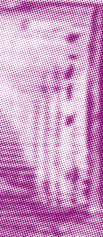

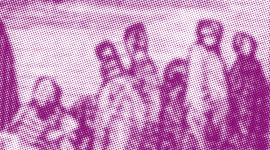
J.
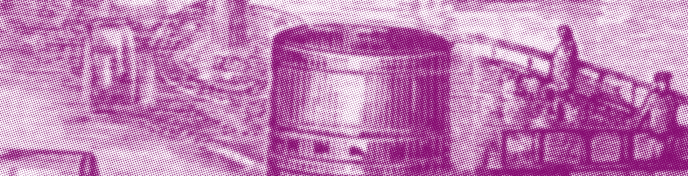

is

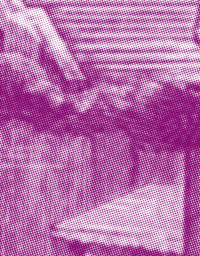

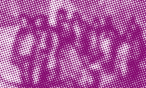

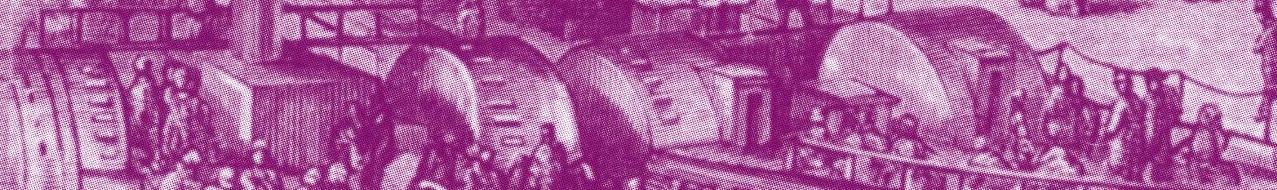
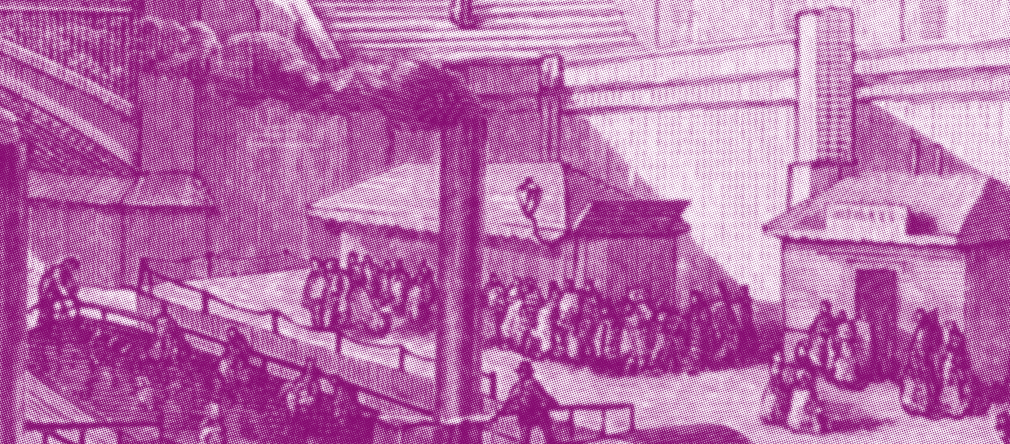

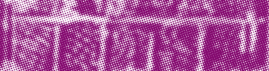

$+2$

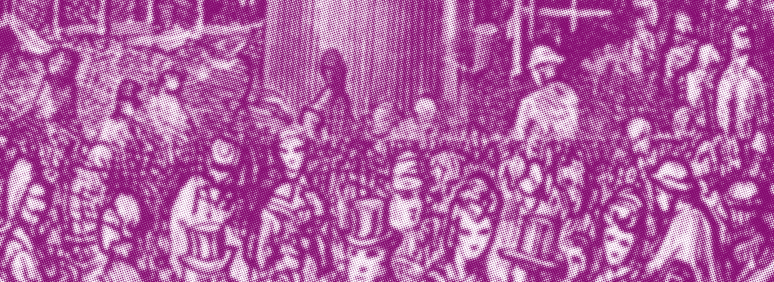

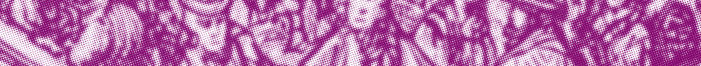

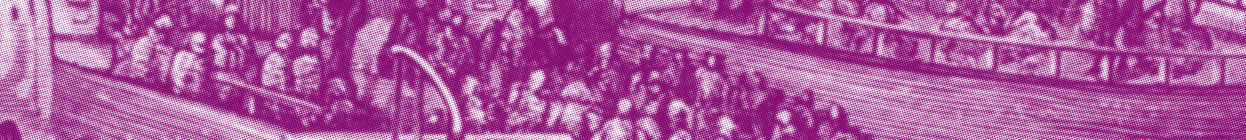




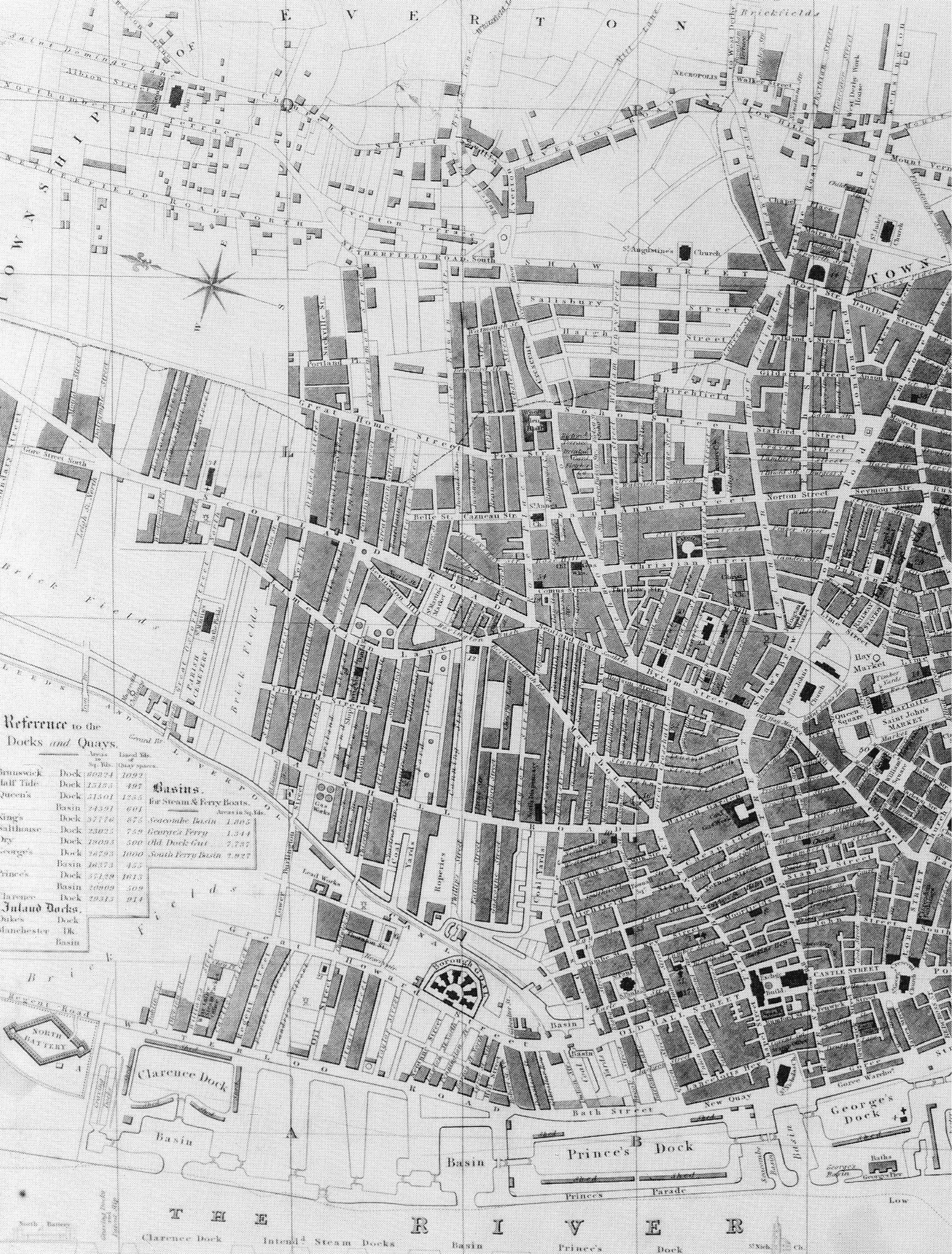




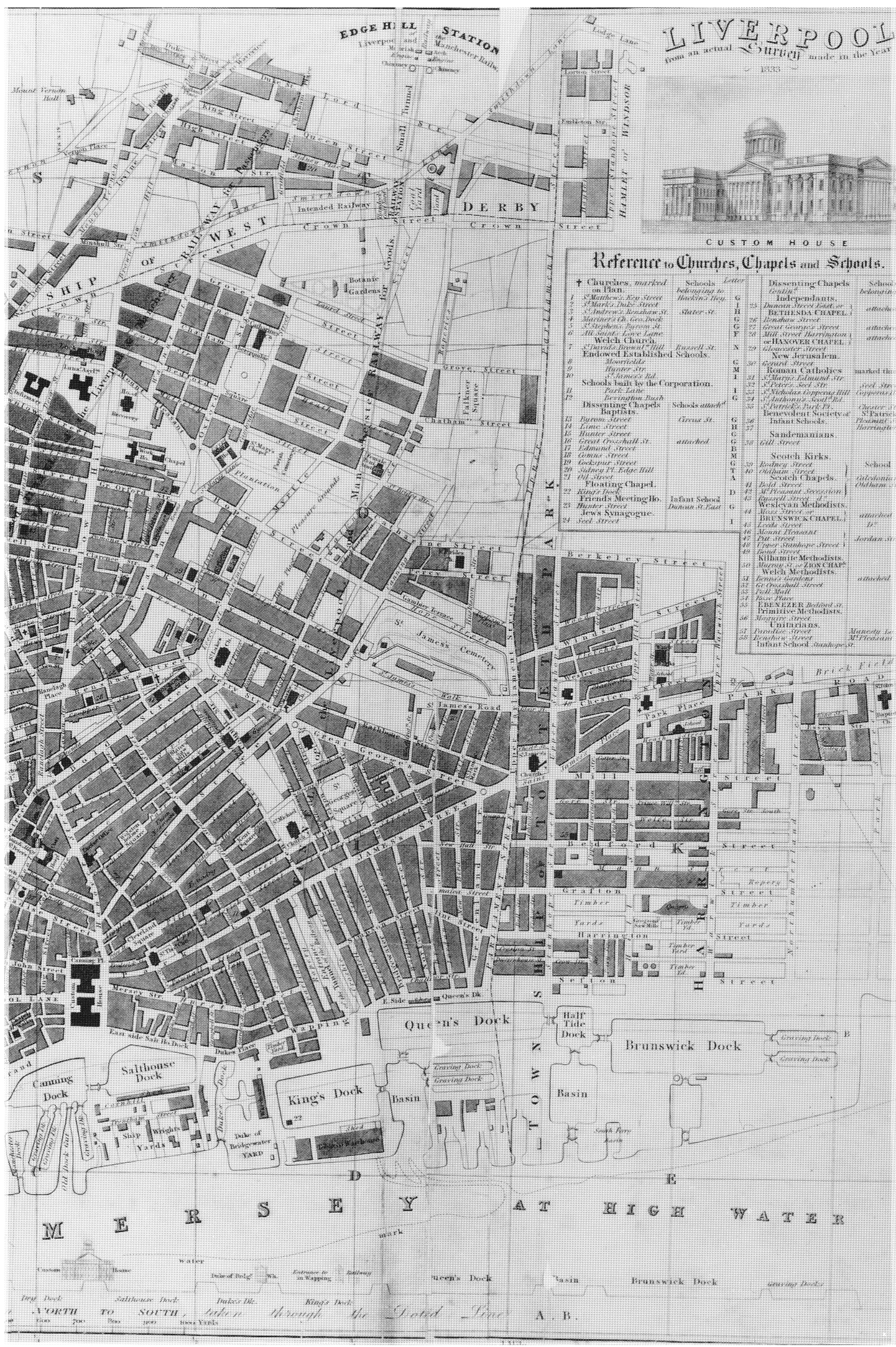




\section{VICTORIAN LITERATURE AND CULTURE}

Volume 40, Number 2 


\section{ADVISORY BOARD}

James Eli Adams

Isobel Armstrong

Nancy Armstrong

Nina Auerbach

Houston A. Baker, Jr.

Tim Barringer

Gillian Beer

Harold Bloom

Patrick Brantlinger

James Buzard

Susan P. Casteras

Ed Cohen

Ian Duncan

Regenia Gagnier

Sandra M. Gilbert

Lauren M. E. Goodlad

Margaret Homans

Audrey Jaffe

Gerhard Joseph

Joseph Kestner

U. C. Knoepflmacher

George Levine

Tricia Lootens

Jane Marcus
Jerome J. McGann

Michael Meredith

J. Hillis Miller

Lynda Nead

Linda Nochlin

Jeff Nunokawa

Mary Poovey

Yopie Prins

Harriet Ritvo

Talia Schaffer

Hilary M. Schor

Linda Shires

Jonah Siegel

E. Warwick Slinn

Ruth A. Solie

Richard Stein

Margaret Stetz

Herbert Sussman

John Sutherland

Herbert Tucker

Martha Vicinus

Malcolm Warner

Michael Wheeler

Carolyn Williams 


\title{
VICTORIAN LITERATURE AND CULTURE
}

Volume 40, Number 2

\author{
EDITORS \\ JOHN MAYNARD \\ ADRIENNE MUNICH
}

\author{
Associate Editor: Sandra Donaldson \\ Managing Editor: Abigail Burnham Bloom \\ Assistant Editors: Daniel Cook, Genevieve Gagne-Hawes, \\ Tamar Heller, Carmen R. Henkel, Tracy Miller, Karen Odden, \\ Tom Pold, Benedick G. Turner, and Stephanie Wardach \\ Editors for Reviews: Winifred Hughes and Anne Humpherys \\ Associate Editor for Reviews: Annette T. Snape \\ Pictures Editor: Morna O’Neill \\ Editor for Topics: Maria Jerinic \\ Special Effects Editor: Jeffrey Spear \\ Editor for Victorians Live: Herbert Sussman \\ CAMBRIDGE UNIVERSITY PRESS \\ 2012
}


VICTORIAN LITERATURE AND CULTURE is a publication of Cambridge University Press. It is published through the generous support of New York University, the State University of New York at Stony Brook, and the University of North Dakota. The editors gratefully acknowledge our indebtedness to our interns and our editorial assistants Lauryn Gold and Margaret Wright Kennedy.

Please email manuscripts to the editors in Word or RTF format: VLCjournal@gmail.com. Articles should be doublespaced throughout and follow the new MLA style (with a list of Works Cited at the conclusion). Chapters of books submitted for the Works in Progress section may follow the author's chosen style in the book project.

Correspondence concerning review essays should be emailed to either Winifred Hughes (winnie.spar@verizon.net) or Anne Humpherys (AHumpherys@gc.cuny.edu).

Suggestions for reprints of Victorian materials, texts, or illustrations, and also bibliographic or other kinds of summary work should be emailed to Jeffrey Spear (Jeffrey.Spear@nyu.edu).

Ideas for Editors' Topics (groups of articles on a common subject, issue, or approach) should be raised with Maria Jerinic (mjerinic@yahoo.com).

Ideas for Victorians Live (the afterlife of the Victorians, the ways that Victorian literature and culture remain alive, continue to live in our own day) can be e-mailed to Herbert Sussman (Hlsuss@ aol.com).

Our website for contents of prior volumes and editorial information:

https://wikis.nyu.edu/display/engvlc/home/

E-mail for general correspondence (not submission of papers): vlc.journal@nyu.edu

Publishing, Subscription, and Advertising Offices: Cambridge University Press, 32 Avenues of the Americas, New York, NY 10013-2473, USA (for the United States, Canada, and Mexico); and Cambridge University Press, The Edinburgh Building, Shaftesbury Road, Cambridge CB2 8RU, England (for U.K. and elsewhere).

Victorian Literature and Culture is published biannually in March and September. 2012 Annual institutional subscription rates (print and electronic): US \$226.00 in the U.S., Canada, and Mexico, UK $£ 136.00$ elsewhere; (electronic only) US $\$ 188.00$ in the U.S., Canada, and Mexico, UK $£ 113.00$ elsewhere; (print only) US $\$ 211.00$ in the U.S., Canada, and Mexico, UK $£ 126.00$ elsewhere. Individual rates (print only): US \$55.00 in the U.S., Canada, and Mexico; UK £ 33.00 elsewhere.

E-mail for orders and subscription information: journals-subscriptions@ cambridge.org

The Cambridge University Press website for Victorian Literature and Culture is: http://journals.cambridge.org/vlc

(C) Cambridge University Press 2012. All rights reserved. No part of this publication may be reproduced, in any form or by any means, electronic, photocopy, or otherwise, without permission in writing from Cambridge University Press. For further information see http://us.cambridge.org/information/rights/ or http://www.cambridge.org/uk/information/rights/

All rights reserved. No part of this publication may be reproduced in any form or by any means, electronic, photocopying, or otherwise, without permission in writing from Cambridge University Press. Photocopying information for users in the U.S.A.: The Item-Fee Code for this publication (1060-1503/11 \$15.00) indicates that copying for internal or personal use beyond that permitted by Sec. 107 or 108 of the U.S. Copyright Law is authorized for users duly registered with the Copyright Clearance Center (CCC), provided that the appropriate remittance of $\$ 15.00$ is paid directly to: CCC, 222 Rosewood Drive, Danvers, MA 09123. Specific written permission must be obtained for all other copying.

Printed in the United States of America.

Postmaster: Send address changes in the U.S., Canada, and Mexico to: Victorian Literature and Culture, Journals Department, Cambridge University Press, 100 Brook Hill Drive, West Nyack, NY 10994-2133. 


\section{CONTENTS \\ VOLUME 40, NUMBER 2}

Imperial Decadence: The Making of the Myths in Edward Bulwer-Lytton's

The Last Days of Pompeii

WILLIAM ST CLAIR AND ANNIKA BAUTZ

John Keble's The Christian Year: Private Reading and Imagined National

Religious Community

JOSHUA KING

Representing the "Hungry Forties" in Image and Verse: The Politics of Hunger in

Early-Victorian Illustrated Periodicals

CHARLOTTE BOYCE

A Pledge Out of Time: Redemption and the Literary Pawnshop

ELIZABETH COGGIN WOMACK

Shakespeare's Victorian Legacy: Text as Monument and Emendation

as Desecration in the Mid-Nineteenth Century

GEORGE YEATS

Into Unorthodox London: The Religious Ethnography of Charles Maurice Davies

FRANCIS DODSWORTH AND SOPHIE WATSON

Character Crisis: Hegemonic Negotiations in Robert Louis Stevenson's

Strange Case of Dr. Jekyll and Mr. Hyde

BENJAMIN D. O'DELL

"Some Trick of the Moonlight": Seduction and the Moving Image in

Bram Stoker's Dracula

DANIEL MARTIN

Chivalric Machines: The Boer War, the Male Body, and the Grand Narrative in the Strand Magazine

J. L. CRANFIELD

\section{WORKS IN PROGRESS}

George Augustus Sala: A Visual Apprenticeship

PETER Blake

vii 
Cosmopolitan Realism: Portable Domesticity in Brontë's Belgian Novels RICHARD BONFIGLIO

Commodity and Identity in Great Expectations

SEAN GRASS

Index 


\section{ILLUSTRATIONS}

Page 362

Figure 1. After Franz Kirchbach, "Dressing Room of a Pompeian Beauty.” Engraved illustration from Edward Bulwer Lytton, The Last Days of Pompeii (London and New York: Routledge, c1900). Private Collection.

Page 363

Figure 2. J. J. Waddington, after E. F. Sherie, “'Drink, feast, love, my pupil!' said he; 'blush not that thou art passionate and young." Etching. The Last Days of Pompeii (London: G. J. Howell, c 1900). Private collection.

Page 365

Figure 3. After Franz Kirchbach, "The Hour is Come!” Engraved illustration from The Last Days of Pompeii (London and New York: Routledge, c1900). Private Collection.

Page 372

Figure 4. Nydia throwing herself into the sea. Engraved illustration from Oxenford's The Last Days of Pompeii. Illustrated London News, 27 Jan. 1872. Private Collection.

Page 373

Figure 5. Pavilion Theatre's Playbill for The Last Days of Pompeii, or the City of the Dead! As Designated by the Immortal Sir Walter Scott. 1835. Victoria and Albert Museum, Theatre and Performance Archives.

Page 376

Figure 6. The Brute Tamer of Pompeii; or, the living lions of the jungle. Performed at Astley's Royal Amphitheatre, London, Aug 1838. Narrativized play: Tales of the Drama. London: E. Lloyd. Hamilton College, New York. Courtesy of Christian Goodwillie. 
Page 377

Figure 7. (Color online) Juvenile drama, portrait of the American-animal trainer Isaac van Amburgh, as the Brute-Tamer of Pompeii. c 1838. Cut out, hand colored, and mounted on blue linen. Private collection.

Page 378

Figure 8. The Last Days of Pompeii performed at Manhattan Beach. Pyrodrama by James Pain. From Harper's Weekly, 1885. British Library by permission.

Page 380

Figure 9. W. Greatbatch after a painting by W. Wright, "Turning, he beheld Nydia kneeling before him, holding up to him a handful of flowers." Engraved frontispiece from The Last Days of Pompeii (London: Bentley 1839). Private collection.

Page 381

Figure 10. W. Greatbatch after a painting by W. Wright, "The beast evinced no sign either of wrath or hunger; its tail drooped along the sand instead of lashing its gaunt sides; and its eye, though it wandered at times to Glaucus, rolled again listlessly from him."

Title page vignette from The Last Days of Pompeii (London: Bentley 1839). Private Collection.

Page 382

Figure 11. After Hablot K. Browne. Engraved frontispiece from The Last Days of Pompeii (London: Chapman and Hall, 1850). Private collection.

Page 384

Figure 12. After Franz Kirchbach, "Nydia leading Glaucus and Ione," Engraved illustration from The Last Days of Pompeii (London and New York: Routledge, c1900). Private Collection.

Page 386

Figure 13. After Lancelot Speed, "Amidst the crashing elements: he had not received the permission to desert his station." Engraved illustration from The Last Days of Pompeii (London: Nisbet, c 1900). Private Collection. 
Page 387

Figure 14. After Frederick Gilbert, "Athenian, resist me, and thy blood be on thine own head." Engraved title page from The Last Days of Pompeii (London: Dicks, 1883). Courtesy of the British Library. A number of the Gilbert illustrations were also used in editions published by Ward \& Lock.

Page 388

Figure 15. (Color online) After Charles Atamian, "The volcanic mountain, dazzling with a sinister splendour, was no more than a column of fire burning the earth and the heavens." Illustration from Les Derniers Jours de Pompéi, Adaptation inédite, ornée de 40 aquarelles de Ch. Atamian (Paris: Linsson, early 20th century). Private collection.

Page 427

Figure 16. “The Pauper's Song.” Engraving from Punch 8 (1845): 38. Courtesy of Cardiff University Library: Special Collections and Archives.

Page 429

Figure 17. "Dorsetshire Peasantry.” Engraving from the Illustrated London News, 5 Sept. 1846: 157. Courtesy of Cardiff University Library: Special Collections and Archives.

Page 434

Figure 18. "Derrynane Beg - Interior of J. Shar's Cabin.” Engraving from the Pictorial Times, 24 Jan. 1846: 57. Courtesy of the National Library of Scotland.

Page 435

Figure 19. James Mahony, "Ballydehob, from the Skibbereen Road." Engraving from the Illustrated London News, 20 Feb. 1847: 117. Courtesy of Cardiff University Library: Special Collections and Archives.

Page 436

Figure 20. James Mahony, "Woman Begging at Clonakilty." Engraving from the Illustrated London News, 13 Feb. 1847: 100. Courtesy of Cardiff University Library: Special Collections and Archives. 
Page 437

Figure 21. James Mahony, "Boy and Girl at Cahera." Engraving from the Illustrated London News, 20 Feb. 1847: 116. Courtesy of Cardiff University Library: Special Collections and Archives.

\section{Page 438}

Figure 22. "Bridget O'Donnel and Children." Engraving from the Illustrated London News, 22 Dec. 1849: 404. Courtesy of Cardiff University Library: Special Collections and Archives.

Page 439

Figure 23. "Miss Kennedy Distributing Clothing at Kilrush.” Engraving from the Illustrated London News, 22 Dec. 1849: 404. Courtesy of Cardiff University Library: Special Collections and Archives.

\section{Page 441}

Figure 24. "Irish Armed Peasants Waiting for the Approach of a Meal Cart.” Engraving from the Pictorial Times, 30 Oct. 1847: 281. Courtesy of the National Library of Scotland.

Page 442

Figure 25. "Meal Cart, Under Military Escort, Proceeding to a Relief Station, Clonmel." Engraving from the Pictorial Times, 30 Oct. 1847: 281. Courtesy of the National Library of Scotland.

\section{Page 443}

Figure 26. "Here and There; Or, Emigration a Remedy." Engraving from Punch 15 (1848): 26. Courtesy of Cardiff University Library: Special Collections and Archives.

\section{Page 460}

Figure 27. George Cruikshank, “The Pawnbroker's Shop.” Illustration from Charles Dickens, Sketches by Boz: Illustrative of Every-day Life and Every-day People. 2 vols. (London: Chapman \& Hall, Ltd.; New York: Charles Scribner's Sons, 1910), 1:220. Courtesy of the Armstrong Browning Library at Baylor University, Waco, Texas. 
Page 482

Figure 28. Anon., "Shakspeare and the Pigmies." Illustration from Punch (30 Jan.1864): 44. Courtesy of the English Faculty Library, Cambridge University.

Page 513

Figure 29. Charles Raymond Macauley, "Mr. Utterson.” Illustration from the chapter "Story of the Door" in Robert Louis Stevenson, The Strange Case of Dr. Jekyll and Mr. Hyde (New York: Scott-Thaw, 1904), 14.

Page 516

Figure 30. Charles Raymond Macauley, "Clubbed him to the earth." Photomechanical illustration from the chapter "The Carew Murder Case" in Robert Louis Stevenson, The Strange Case of Dr. Jekyll and Mr. Hyde (New York: Scott-Thaw, 1904), 62.

Page 518

Figure 31. Charles Raymond Macauley, "Mr. Utterson, sir, I'm afraid." Illustration from the chapter "The Last Night" in Robert Louis Stevenson, The Strange Case of Dr. Jekyll and Mr. Hyde (New York: Scott-Thaw, 1904), 104.

Page 536

Figure 32. [Loie Fuller, full-length portrait, standing, facing front; raising her gown in the shape of a butterfly]. Photographic Print. c1902. Library of Congress.

Page 537

Figure 33. (Color online) Annabelle Serpentine Dance. Dir. Thomas Edison. Perf. Annabelle Whitford Moore. Edison, 1895. Kino Video.

Page 538

Figure 34. Étienne-Jules Marey. Course de l'homme. Chronophotograph. c1890. Courtesy of La Cinémathèque Française.

Page 539

Figure 35. Eadweard Muybridge, "Plate 73. Movements, Female, Turning Around in Surprise and Running Away" from Animal Locomotion (Philadelphia: J. B. Lippincott, 1887). University of Pennsylvania Archives. 
Page 540

Figure 36: Eadweard Muybridge, "Plate 416. Movements, Female, Toilet; Putting on dress" from Animal Locomotion (Philadelphia: J. B. Lippincott, 1887). University of Pennsylvania Archives.

Page 553

Figure 37. Arthur Weston, "Taking mould of back and shoulders." Photomechanical reproduction. Strand Magazine 22 (Oct. 1901): 461.

Page 556

Figure 38. After W. S. Stacey, "I won't stay here and hear him slandered." Illustration from Strand Magazine 1 (Jan. 1891): 314.

Page 557

Figure 39. After W. S. Stacey, “Call me Charles. Do now.” Illustration from Strand Magazine 1 (Jan. 1891): 315.

Page 558

Figure 40. After Sidney Paget, “'Mr. Hall Pycroft, I believe?' Said he.” Illustration from Strand Magazine 5 (Jan. 1893): 283.

Page 560

Figure 41. After Sidney Paget, "An instant later the tutor returned, bringing with him the student.” Illustration from Strand Magazine 27 (June. 1904): 611.

Page 562

Figure 42. After W. Dewar, "Mrs. Hussingtree looked at him, saw his graveness, and turned towards the house. 'It's Joyce, Harry?' she questioned." Illustration from Strand Magazine 43 (Sep. 1912): 649.

Page 568

Figure 43. “Trooper Clifford Turpin.” Photomechanical reproduction. Strand Magazine 20 (Aug. 1900): 155. 
Page 569

Figure 44. "Sergeant Boseley." Photomechanical reproduction. Strand Magazine 20 (Aug. 1900): 156.

Page 580

Figure 45. George Cruikshank, title page for Charles Dickens, Sketches by Boz (London: John Macrone, 1842). Courtesy of Beinecke Rare Book and Manuscript Library, Yale University.

Page 591

Figure 46. G. A. Sala, frontispiece for Alfred Bunn, A Word With Punch (London: St. Martin's Lane, Charing Cross, 1847). Courtesy of the British Library.

Page 594

Figure 47. Anon. [G. A. Sala], The Heads of the Headless (Lloyd and Calvert, 1847).

Reproduced in Ralph Straus, Sala: Portrait of an Eminent Victorian (London: Constable \& Co., 1942), 56. 


\section{CAMBridge}

\section{Available from Cambridge University Press}

Emily Dickinson and the Religious Imagination

Linda Freedman

\$90.00: Hb: 978-1-107-00617-1: 200 pp.

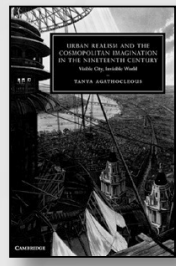

Urban Realism

and the

Cosmopolitan Imagination in the Nineteenth Century

Visible City, Invisible World

Tanya Agathocleous

Cambridge Studies in NineteenthCentury Literature and Culture \$90.00: Hb: 978-0-521-76264-9: 294 pp.

Tuberculosis and the Victorian Literary Imagination

Katherine Byrne

Cambridge Studies in NineteenthCentury Literature and Culture \$90.00: Hb: 978-0-521-76667-8: $240 \mathrm{pp}$.

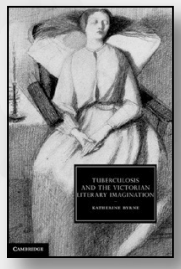

\begin{tabular}{l}
\multicolumn{1}{|c|}{$\begin{array}{l}\text { THE CAMBRIDGE EDITION OF } \\
\text { THE WORKS OF JOSEPH CONRAD }\end{array}$} \\
Suspense \\
Edited by GENE M. MOORE \\
\$125.00: Hb: 978-0-521-82353-1: \\
510 pp. \\
Last ESSayS \\
Edited by \\
HAROLD RAY STEVENS \\
and J. H. STAPE \\
Assisted by MARY BURGOYNE \\
and ALEXANDRE FACHARD \\
\$120.00: Hb: 978-0-521-19059-6: \\
536 pp. \\
\hline
\end{tabular}

Prices subject to change.
Charles Dickens in Context

Edited by SALLY LEDGeR

and Holly Furneaux

Literature in Context

\$110.00: Hb: 978-0-521-88700-7: $428 \mathrm{pp}$.
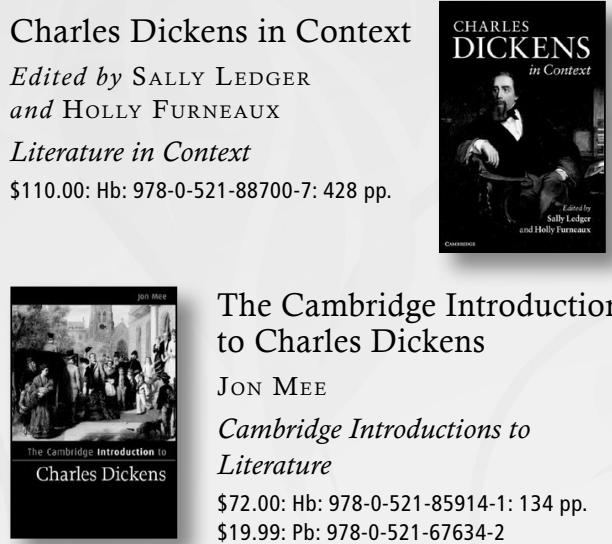

The Cambridge Introduction to Charles Dickens

Jon MeE

Cambridge Introductions to Literature

\$72.00: Hb: 978-0-521-85914-1: $134 \mathrm{pp}$ \$19.99: Pb: 978-0-521-67634-2

The Cambridge Introduction to Victorian Poetry

Linda K. Hughes

Cambridge Introductions to Literature

\$85.00: Hb: 978-0-521-85624-9: 344 pp. \$27.99: Pb: 978-0-521-67224-5
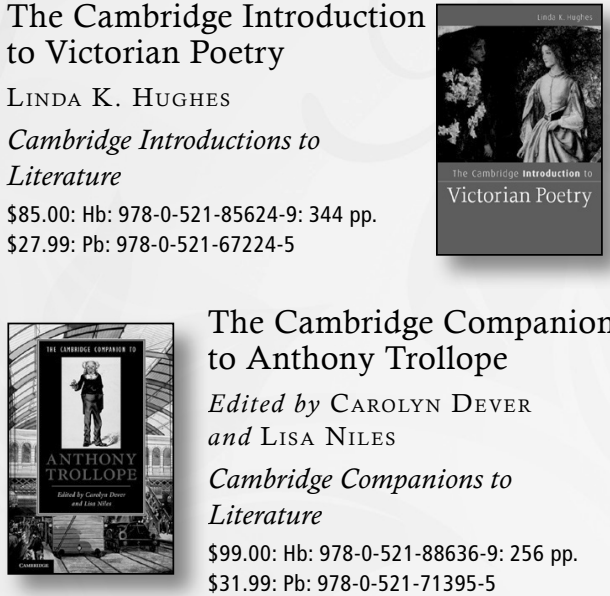

The Cambridge Companion to Anthony Trollope

Edited by CArolyn Dever and Lisa Niles

Cambridge Companions to Literature

\$99.00: Hb: 978-0-521-88636-9: $256 \mathrm{pp}$. \$31.99: Pb: 978-0-521-71395-5

\section{NOW AVAILABLE IN PAPERBACK!}

The Brontës and Education

MARIAnNe ThormäHLEN

\$39.99: Pb: 978-0-521-15561-8: 318 pp.

George Eliot's Intellectual Life

Avrom Fleishman

\$39.99: Pb: 978-1-107-40266-9: 308 pp. 